\title{
Juridical Analysis of Delegation of Authority Medical Treatment (Verdict Case Study No.1165/PID.B/2010/PN.SDA, No.1166/PID.B/2010/PN.SDA, NO.1167/PID.B/ 2010/PN. SDA.)
}

\author{
Analisis Yuridis Pelimpahan Wewenang Tindakan Medis \\ (Studi Kasus Putusan No.1165/PID.B/2010/PN.SDA, NO.1166/ \\ PID.B/2010/PN.SDA, NO.1167/PID.B/ 2010/PN. SDA.) \\ Juliana Susanti, M. Nasser, Petrus Soerjowinoto \\ email: dr julianasusanti@yahoo.com
}

Health Law Master Program, Soegijapranata Catholic University of Semarang

\begin{abstract}
Since September 2014, The House of Representatives passed a new Nurses Act, Act $\mathrm{Nr} .38$ of 2014. Nurses Act is considered legal protection for nurses in Indonesia and defines their scope of practice. The Act was developed and passed with the specific aim to improve professional quality and the quality of nursing care. Nurses are legally permitted to prescribe limited medical treatment based on physicians' delegation or mandated orders. All of these actions will be regulated by codes from the Ministry of Health, which will be derived from the new Nurses Act and with consideration of the nurse's competencies to perform such specific medical interventions. This study to examine the extent to which the doctor as general practitioner delegated medical treatment to the nurses and to analyze procedure towards authority delegation from doctor to nurses. As usual, both doctor and nurses were reluctant to have minor clinical treatment delegated and a majority did not think that nurses should carry out delegated diagnostic procedures. Doctors and nurses who had completed their training were more likely to favor delegation since this decade so that delegation may become more common, for example in favor of delegating injections, dressings and stitch removal and immunizations. There is no clear definition of the scope of practice for the nurse in the field, in contrary delegation among those with unfavorable views often appeared formidable. Nurses need reeducating before such a system could. It is dangerous to have someone who'sundertrained.
\end{abstract}

The delegation of medical treatment should consider patient safety and comfort. This research applied the normative juridical method with legal clinical research (prescriptive normative) based on library approach, and case approach consisted of secondary data that gathered by rules, regulations, and verdict case number 1165/Pid.B/2010/PN.SDA, 1166/Pid.B/2010/PN.SDA and 1167/Pid.B/2010/PN.SDA and interviews with a law firm and legal consultant who handled the case verdict about delegation of authority medical treatment from a doctor to nurse. The result of the study showed there are limitation procedures of regulation to perform medical treatments based on physicians' delegation or mandated orders. Therefore health policymaker should make regulations of the scope of medical treatment procedure based on responsibility and authority delegation from doctor to nurse.

Keywords: authority, delegation, procedures, medical treatment, verdict case. 


\section{PENDAHULUAN}

Manusia sebagai makhluk sosial pada hakekatnya selalu ingin berkumpul dengan sesamanya, Aristoteles menyebutnya sebagai zoon politicon'. Dalam pemenuhan kebutuhan terjadi hubungan antar manusia satu dengan lainnya yang dapat menimbulkan konfik kepentingan (conflict of interest), sehingga perlunya suatu pedoman bertingkah laku agar tidak saling merugikan disebut dengan Kaidah atau Norma ${ }^{2}$. Kumpulan dari kaidah atau norma disebut dengan Peraturan yang menurut Wila berdasarkan bentuknya ada peraturan tertulis dan ada yang tidak tertulis serta pembagian peraturan berdasarkan bidang pengaturannya yaitu peraturan hukum dan peraturan non hukum ${ }^{3}$. Dalam penelitian ini selanjutnya yang dipakai adalah peraturan hukum.

Setiap aktivitas manusia pasti ada hukumnya (ubi societas ibi ius) demikian juga praktik penyelenggaraan kesehatan harus mempunyai pranata hukum yang disebut hukum kesehatan. Hukum kesehatan (health law) mengatur pelayanan kesehatan pada umumnya dapat dibagi lagi menjadi hukum yang mengatur pelayanan kesehatan masyarakat (public health law) dan hukum yang mengatur pelayanan kesehatan perseorangan yang disebut dengan hukum kedokteran (medical law) ${ }^{4}$. Selanjutnya dalam penelitian ini akan memakai peraturan peraturan yang sesuai dengan hukum kedokteran. Hukum kedokteran lebih spesifik mengatur tentang pelaksanaan pelayanan kesehatan yang dilakukan oleh sumber daya kesehatan yang terdiri dari: Sumber Daya Manusia Kesehatan (yang disingkat SDMK) terdiri dari dokter sebagai tenaga medis dan tenaga kesehatan seperti perawat dan Rumah Sakit, dimana mempunyai obyek yang sama yaitu sasaran tunggalnya adalah pemenuhan hak asasi pasien.Spesifikasi Medical Law bertolak atas asas pemenuhan hak dasar sosial perawatan kesehatan (the right to health care) dan hak dasar individual yaitu hak untuk menentukan nasib sendiri (the right to self determination) $)^{5}$

Karakteristik bidang jasa kesehatan sangat berbeda dengan bidang jasa lain, dimana jasa kesehatan tidak dapat dipenuhi sendiri oleh individu melainkan harus disediakan atau diusahakan oleh pihak pihak khusus yang memerlukan campur tangan pemerintah sesuai yang diamanatkan dalam Pasal 34 ayat (3) UUD 1945 bahwa: "Negara bertanggung jawab atas penyediaan fasilitas pelayanan kesehatan dan fasilitas pelayanan umum yang layak". Pemenuhan ketersediaan jasa kesehatan sangat vital bagi warganya sehingga perlu adanya standarisasi yang diprakarsai oleh pemerintah yang diwujudkan dalam Sistem Kesehatan Nasional (selanjutnya disingkat SKN).

Pasal1 butir 2 Peraturan Presiden Republik Indonesia Nomor 72 Tahun 2012 Tentang Sistem Kesehatan Nasional disebutkan bahwa SKN merupakan "Pengelolaan kesehatan yang diselenggarakan oleh semua komponen bangsa Indonesia secara terpadu dan saling mendukung guna menjamin tercapainya derajat kesehatan masyarakat yang setinggitingginya", selanjutnya Pasal 3 ayat (1) huruf a dan huruf d menyebutkan bahwa upaya kesehatan dan Sumber Daya Manusia Kesehatan (selanjutnya disingkat SDMK) merupakan salah satu ketujuh subsistem dalam komponen SKN. Sumber daya kesehatan terdiri dari sarana, prasarana dan peralatan yang diistilahkan sebagai perangkat keras (hardware) dan

\footnotetext{
${ }^{1}$ Petrus Soerjowinoto,2015, Ilmu Hukum Suatu Pengantar Buku Panduan Mahasiswa,Semarang: Unika Soegijapranata, hal. 12.

${ }^{2}$ Ibid, hal.14.

${ }^{3}$ Wila Chandrawila Supriadi, 2001, Hukum Kedokteran, Bandung: Mandar Maju, hal.4

${ }^{4}$ Ibid, hal.7.

${ }^{5}$ Moh.Hatta, 2013, Hukum Kesehatan dan Sengketa Medik, Yogyakarta: Liberty, hal. 2.
} 
perangkat lunak (software) yang terdiri dari manajemen, pembiayaan, dan sumber daya manusia ${ }^{6}$.

Upaya kesehatan perseorangan pada awalnya sebagai upaya penyembuhan penderita yang dilakukan secara terpadu,menyeluruh, dan berkesinambungan dengan pendekatan promotif, preventif, kuratif dan rehabilitatif ${ }^{7}$ melalui tujuh belas macam kegiatan diantaranya adalah pelayanan kesehatan seperti yang tercantum dalam Pasal 46 sampai dengan Pasal 51 UU No.36 Tahun 2009 Tentang Kesehatan (selanjutnya disebut UU Kesehatan) sedangkan Pasal 52 sampai dengan Pasal 55 UU Kesehatan yang mengatur tentang Pelayanan Kesehatan menjelaskan bahwa pelayanan individu lebih mengutamakan penyembuhan penyakit dan pemulihan kesehatan, dilaksanakan secara bertanggung jawab, aman, bermutu, merata dan nondiskriminatif. Pemerintah bertanggung jawab dalam hal perencanaan, pengaturan, penyelenggaraan, pembinaan dan pengawasan upaya kesehatan yang merata dan terjangkau oleh masyarakat, ketersediaan sumber daya kesehatan beserta aksesnya diaturdalam Pasal 14 sampai dengan Pasal 19 UU Kesehatan. Kewenangan tenaga kesehatan dalam pelayanan kesehatan diberikan pemerintah dengan persyaratan sebagai berikut : "memiliki keahlian yang sesuai dengan pelayanan yang diberikan,memenuhiketentuan Kode Etik, Standar Profesi, hak pengguna pelayanan kesehatan, Standar Pelayanan, dan Standar Prosedur Operasional (selanjutnya disingkat SPO)" diatur dalam Pasal 23 jo Pasal 24 UU Kesehatan.

Kewenangan Dokter dalam melaksanakan praktik kedokteran diperoleh setelah dokter memenuhi prosedur persyaratan perizinan praktik kedokteran yang tertuang dalam Pasal 29 jo Pasal 36 UU Praktik Kedokteran yaitu : "memiliki ijazah, mengucapkan sumpah/ janji dokter, sehat fisik dan mental, memiliki Sertifikat Kompetensi dan Surat Tanda Registrasi (selanjutnya disebut STR) yang dikeluarkan oleh Konsil Kedokteran Indonesia(selanjutnya disingkat KKI) dan Surat Izin Praktik (selanjutnya disebut SIP) sesuai dengan pendidikan dan kompetensi yang dimilikinya", selanjutnya Pasal 35 ayat (1) menegaskan jenis tindakan yang merupakan kewenangan dokter, diantaranya: "menegakkan diagnosis, menentukan penatalaksanaan dan pengobatan pasien serta melakukan tindakan kedokteran, ayat(2) menjelaskan batasan kewenangan tindakan medis dokter sesuai dengan sertfikat kompetensi". Perlindungan hukum terhadap tindakan medis yang dilakukan dokter diperoleh sepanjang dokter memberikan pelayanan medis sesuai dengan Standar Profesi dan SPO. Penjelasan Pasal 50 UU Praktik Kedokteran mengatakan bahwa :

"Dokter dan dokter gigi dengan perangkat keilmuan yang dimilikinya mempunyai karakteristik yang khas. Kekhasannya ini terlihat dari pembenaran yang diberikan oleh hukum yaitu diperkenankannya melakukan tindakan medis terhadap tubuh manusia dalam upaya memelihara dan meningkatkan derajat kesehatan. Tindakan medis terhadap tubuh manusia yang dilakukan bukan oleh dokter atau dokter gigi dapat digolongkan sebagai tindak pidana".

Kewenangan dokter dalam memberikan pelayanan medis sesuai dengan SPM dan SPO telah diatur dalam Pasal 51 huruf (a) dan (b) Undang Undang Nomor 29 tahun 2004 tentang Praktik Kedokteran (selanjutnya disebut UU PraktekKedokteran). Praktik Kedokteran

\footnotetext{
${ }^{6}$ Hermien Hadiati Koeswadji, 1998, Hukum Kedokteran (Studi Tentang Hubungan Hukum Dalam Mana Dokter Sebagai Salah Satu Pihak), Bandung : PT.Citra Aditya Bakti, hal. 105.

${ }^{7}$ Bahder Johan Nasution, 2005,Hukum Kesehatan Pertanggung Jawaban Dokter, Jakarta : PT. Rineka Cipta, hal.2.
} 
dilakukan dokter dengan kehati-hatian dan ketelitian sesuai standar yang telah ditetapkan peraturan perundangan, standar profesi dan standar peraturan internal rumah sakit.Dokter memiliki tanggung jawab hukum dan profesi.Setiap orang dapat mengadukan secara tertulis kepada Ketua Majelis Kehormatan Disiplin Kedokteran Indonesia (selanjutnya disingkat MKDKI) dan dapat juga melaporkan dokter kepada pihak yang berwenang secara perdata dan/atau secara pidana bila diduga melakukan tindakan yang merugikan sesuai dengan ketentuan Pasal 66 ayat (1) dan ayat (3) UU Praktik Kedokteran.

Dokter dan perawat adalah mitra kesehatan yang paling dekat dalam upaya penyembuhan pasien sesuai bidang ilmu pengetahuan dan kompetensinya guna menunjang pelayanan kesehatan yang bermutu. Sejak keluarnya Undang Undang nomor 38 tahun 2014 tentang Keperawatan (selanjutnya disebut UU Keperawatan), paradigma praktik keperawatan telah bergeser dari perawat vokasional yang hanya sebagai perpanjangan tangan dokter menjadi perawat profesional yang sejajar dan bermitra dengan dokter.Perawat diberi kewenangan secara mandiri melakukan praktik keperawatan dan dapat bekerja di Fasilitas Pelayanan Kesehatan (selanjutnya disingkat Fasyankes) seperti Rumah Sakit. Tanggung jawab perawat berhubungan dengan pemberian pelayanan asuhan keperawatan (caring) dan perawatan (nurturing), bukan pengobatan (cure) yang merupakan otoritas dokter seperti halnya juga pemberian obat yang merupakan tugas apoteker seringkali dilimpahkan kepada perawat.

Otoritas dokter dalam pelaksanaan tindakan medis dapat dilimpahkan wewenangnya secara terbatas kepada perawat sesuai tata cara (prosedur) dan syarat syarat pelimpahan wewenang diatur dalam Pasal 23 Permenkes No. 2052/Menkes/Per/X/2011 Tentang Izin Praktik dan Pelaksanaan Praktik Kedokteran. Hal ini seiring dengan salah satu tugas dan wewenang perawat yang diatur dalam Pasal 29 ayat (1) huruf e UU Keperawatan yang menyebutkan bahwa: "Dalam menyelenggarakan Praktik Keperawatan, Perawat bertugas sebagai pelaksana tugas berdasarkan pelimpahan wewenang. Prosedur pelaksanaan dan syarat pelimpahan wewenang dari dokter kepada perawat diatur dalam Pasal 32 UU Keperawatan. Perawat dalam melakukan tugas dan wewenangnya wajib mematuhi prosedur tentang Penyelenggaraan Praktik Keperawatan yang diatur dalam Pasal 8 jo Pasal 9 Permenkes No.HK.02.02/ Menkes/148/1/2010 Tentang Izin dan Penyelenggaraan Praktik Perawat, kewajiban perawat juga diatur dalam Pasal 12 ayat (1) huruf g yaitu mematuhi standar dan pada ayat (2) mengatakan bahwa: "Perawat dalam menjalankan praktik senantiasa meningkatkan mutu dengan mengikuti perkembangan iptek melalui pendidikan dan pelatihan sesuai dengan bidang tugasnya".

Prosedur pelaksanaan pelimpahan wewenang tindakan medis dari dokter kepada perawat belum diatur secara jelas dalam Peraturan Pelaksana Undang Undang seperti Permenkes dan Kebijakan Rumah Sakit yang mengatur tata kelola staf medis (medical staff bylaws) serta SPO pelimpahan wewenang tindakan medis sehingga menimbulkan misperpepsi dan miskomunikasi antara pemberi kewenangan yaitu dokter dan penerima kewenangan yaitu perawat.Akibatnya pelayanan kesehatan tidak mencapai sasaran dan merugikan bagi penerima layanan kesehatan.

Perawat dalam menerima wewenang dari dokter dalam melakukan tindakan medis sering melakukan tindakan yang tidak sesuai dengan SPO dan instruksi dokter.Pertanggungjawaban hukum atas kelalaian yang dilakukan perawat dapat menjerat dokter yang memberi perintah. Tanggung jawab juga disertai dengan tanggung gugat dimana akuntabilitas perawat dalam melaksanakan suatu perbuatan harus sudah mengetahui resiko dan akibat dari perbuatan tersebut. Bila ada gugatan, perawat harus 
berani dan siap dalam membuktikan bahwa tindakan tersebut sudah dilakukan sesuai dengan standar profesinya.

Tuntutan terhadap kelalaian atau kealpaan dalam pertanggungjawaban hukum pidana kedokteran atau pidana medis seringkali menimbulkan frustasi pihak tenaga medis maupun di pihak pasien serta para penegak hukum karena sulitnya pembuktian.Pihak dokter sebagai tergugat perlu membuktikan dalam tindakan medis yang dilakukannya telah mematuhi SPO, Standar Profesi serta Standar Pelayanan Minimal (selanjutnya disingkat SPM) Rumah Sakit dengan mengemukakan alasanalasan atas tindakannya tersebut, sedangkan pasien sebagai penggugat serta profesional praktisi hukum seperti hakim dan jaksa mendapat kesulitan dalammenghadapimasalah minimnya rujukan tentang peraturan yang mengatur teknis prosedur pelimpahan wewenang tindakan medis dari dokter kepada perawat yang dikaitkan dengan kelalaian dalam pasal pasal perundangan yang menimbulkan pidana medis baik memakai hukum kodifikasiKUHP dan KUHAP serta lex generalis UU Kesehatan dan lex spesialis UU Praktik Kedokteran, UU Rumah Sakit, UU Tenaga Kesehatan, dan UU Keperawatan serta turunan dari Undang Undang tersebut setingkat Permenkes.

Dalam penelitian ini, penulis akan melakukan studi kasus Putusan Nomor 1165/Pid.B/2010/PN.SDA, 1166/Pid.B/2010/PN.SDA dan 1167/Pid.B/2010/ PN.SDA tentang peristiwaperbuatan subyek hukum yaitu dokter, perawat vokasi dan siswa magang serta obyek hukumnya adalah hubungan tanggungjawab dan tanggung gugat para pihak subyek hukum yang menimbulkan akibat hukum pelimpahan wewenang tindakan medis. Pelanggaran prosedural tentang persyaratan pelimpahan wewenang timbulnya suatu delik dengan dakwaan primair Pasal 359 KUHP jo Pasal 361 KUHP dan subsidair Pasal 359 KUHP karena kelalaiannya menyebabkan kematian pada seorang anak berusia tiga tahun. Pada putusan tersebut dokter dijatuhi pidana selama delapan bulan penjara, sedangkan perawat serta siswa magang walaupun terbukti bersalah tetapi bukan tindak pidana sehingga lepas dari segala tuntutan karena melaksanakan perintah atasan (vicarious liability).

Ketertarikan penulis dalam mengambil judul "Analisis Yuridis Pelimpahan Wewenang Tindakan Medis (Studi Kasus Putusan Nomor 1165/Pid.B/2010 /PN. SDA, 1166/Pid.B/2010/PN.SDA dan 1167/Pid.B/2010/ PN.SDA)" karena ingin melihat sinkronisasi secara vertikal prosedur pelimpahan wewenang tindakan medis dari dokter kepada perawat berdasarkan Undang Undang secara in abstracto dan kesesuaiannya dengan pelaksanaannya di lapangan secara in concreto berdasarkan studi kasus putusan tersebut.

\section{PERUMUSAN MASALAH}

Berdasarkan latar belakang yang telah diuraikan diatas, maka perumusan masalah yang akan diteliti dalam penulisan ini sebagai berikut:

1. Bagaimana prosedur pelimpahan wewenang tindakan medis dari dokter kepada perawat berdasarkan perundang-undangan?.

2. Bagaimana prosedur pelimpahan wewenang dalam tindakan medis berdasarkan Putusan No.1165/Pid.B/2010/PN.SDA, Putusan No.1166/Pid.B/2010/PN.SDA dan Putusan No.1167/Pid.B/2010/PN.SDA?. 


\section{METODE PENELITIAN}

\section{Metode Pendekatan}

Penelitian ini merupakan penelitian hukum normatif, yang dalam pembahasannya menggunakan disiplin hukum preskriptif analitis dimana hukum dipandang sebagai suatu sistem ajaran tentang norma dengan pendekatan perundang-undangan (statute approach) bersifat dogmatik hukum yaitu kaidah hukum dan ilmu tentang pengertian pokok dalam hukum dan teoritis rasional dengan model penalaran logika deduktif ${ }^{8}$ memberikan argumentasi terhadap studi kasus (case approach) putusan pengadilan yang telah mempunyai kekuatan hukum mengikat dimana satu rangkaian peristiwa hukum tentang pelimpahan wewenang tindakan medis dengan tiga putusan masing terdakwa seorang dokter, perawat vokasi dan siswi magang, dengan hasil putusan membebaskan perawat vokasi dan siswi magang namun memenjarakan dokter, penelitian terhadap taraf sinkronisasi vertikal dan horisontal serta melihat hukum sebagai norma untuk menyelesaikan masalah hukum konkret (perkara hukum dalam putusan kasus tentang kelalaian dokter dan perawat dalam pelimpahan wewenang tindakanmedis) yang dilakukan oleh para praktisi hukum(legal practitioners) ${ }^{9}$ dengan memakai peraturan perundang-undangan yang relevan seperti : KHUP,UU Kesehatan, UU Praktik Kedokteran, UU Rumah Sakit, UU Tenaga Kesehatan, UU Keperawatan dan sinkronisasi turunan UU yaitu Permenkes No. 2052 Tahun 2011 tentang Izin Praktik dan Pelaksanaan Praktik Kedokteran, Permenkes No. 17 Tahun 2013 Tentang Perubahan Atas Peraturan Menteri Kesehatan Nomor Hk.02.02/Menkes/148/1/2010 Tentang Izin danPenyelenggaraan Praktik Perawat, Permenkes No. 290 Tahun 2008 tentang Persetujuan Tindakan Kedokteran,Kepmenkes No. 1239/ MENKES/SK/XI/2001 Tentang Registrasi dan Praktik Perawat, Permenkes No. HK.02.02/MENKES/148/I/2010 Tentang Izin danPenyelenggaraan Praktik Perawat.

\section{Spesifikasi Penelitian}

Spesifikasi penelitian preskriptif analitis dimana data sekunder berupa bahan hukum primer seperti peraturan perundang-undangan serta putusan kasus, bahan hukum sekunder buku dan jurnal serta tersier berupa kamus juga mengkaji teori tentang tanggung jawab hukum dokter sebagai tenaga medis dan perawat sebagai tenaga kesehatan dalam pelimpahan wewenang tindakan medik, regulasi prosedur pelimpahan kewenangan antara dokter dan perawat, batasan batasannya, pelanggaran prosedur pelimpahan kewenangan serta akibat akibat hukum kemudian dilihat sinkronisasi dengan studi kasus PutusanNo.1165/Pid.B/2010/PN.SDA.,PutusanNo.1166/Pid.B/2010/PN.SDA. dan Putusan No.1167/Pid.B/2010/PN.SDA. Kajian hasil pembahasan dipaparkan lengkap, jelas, rinci dan sistematis.

\section{Jenis Data}

Dalam penelitian ini digunakan data sekunder dari bahan pustaka sebagai sumber utamanya (library research). Data sekunder mencakup ${ }^{10}$ bahan hukum primer yaitu UU Kesehatan, UU Praktik Kedokteran, UU Rumah Sakit, UU Keperawatan serta Permenkes

\footnotetext{
${ }^{8}$ Soerjono Soekanto dan Sri Mamudji, 2001,Penelitian Hukum NormatifSuatu Tinjauan Singkat,Jakarta: Raja Grafindo Persada, hal. 14.

${ }^{10}$ Soerjono Soekanto, 1982, Pengantar Penelitian Hukum, Jakarta: Universitas IndonesiaPress, hal.52.
} 
2052 Tahun 2011 tentang Izin Praktik dan Pelaksanaan Praktik Kedokteran, Permenkes Nomor 17 Tahun 2013 Tentang Perubahan Atas Peraturan Menteri Kesehatan Nomor Hk.02.02/Menkes/148/1/2010 Tentang Izin dan Penyelenggaraan Praktik Perawat. kasus Putusan No.1165/Pid.B/2010/PN.SDA., Putusan No.1166/Pid.B/2010/PN.SDA. danPutusan No.1167/Pid.B/2010/PN.SDA.yang telah mempunyai kekuatan hukum mengikat, bahan hukum sekunder yaitu bahan bahan yang memberikan penjelasan mengenai bahan hukum primer seperti buku, jurnal, makalah, seminar serta bahan hukum tertier yaitu yang memberikan petunjuk bahan hukum primer dan sekunder dari media cetak dan elektronik seperti kamus bahasa Indonesia, bahasa Inggris, kamus hukum dan ensiklopedi yang berhubungan dengan penelitian.

\section{Metode Pengumpulan Data}

Penelitian ini menggunakan bahan pustaka yang berupa data sekunder sebagai sumber utamanya. Teknik pengumpulan data adalah studi kepustakaan melalui penelusuran manual maupun elektronik peraturan perundang-undangan, buku-buku, jurnal serta koran atau majalah, dan juga data internet yang yang terkait dengan Prosedur Pelimpahan Wewenang dari Dokter kepada Perawat dalam Tindakan Medis, Prosedur Persyaratan Perizinan Pelaksanaan Praktik Kedokteran dan Praktik Keperawatan, Aspek Hukum Hubungan Dokter, Perawat, Rumah Sakit dan Pasien.

Penelitian ini menggunakan dua macam metode pengumpulan data yaitu data sekunder berupa kumpulan berkas kasus dari penyidik, jaksa dan sidang pengadilan serta foto foto alat bukti yang penulis peroleh dari Ketua Panitera Pengadilan Negeri Sidoarjo dan Panitera Hukum Pengadilan Negeri Sidoarjo sera wawancara dengan penasehat hukum Bambang Soetjipto, S. H., M. Hum yang menangani kasus Putusan No.1165/Pid.B/ 2010/PN.SDA., Putusan No.1166/Pid.B/2010/PN.SDA., Putusan No.1167/Pid.B/2010/PN.SDA.dengan tujuan untuk konfirmasi dan klarifikasi mengenai halhal yang menurut peneliti belum jelas atau diragukan keabsahan dan kebenarannya.

\section{Metode Analisis Data}

Analisa data menggunakan metode kualitatif. Data dikumpulkan, dianalisis secara kualitatif dalam bentuk uraian kalimat dan penjelasan,dan dilanjutkan dengan menarik kesimpulan secara deduktif yaitu suatu cara berpikir yang didasarkan pada fakta-fakta yang bersifat umum, kemudian dilanjutkan dengan pengambilan kesimpulan yang bersifat khusus yang merupakan jawaban dari permasalahan serta akan diberi masukan masukan berupa saran.

Dalam penelitian ini, pengolahan keseluruhan data yang telah Penulis peroleh baik dari wawancara maupun studi kepustakaan dari bahan hukum primer, sekunder, dan tersier, dilakukan secara sistematis dan kualitatif agar menghasilkan tulisan yang preskriptif analitis mengenai bagaimana prosedur pelimpahan wewenang tindakan medis dari dokter kepada perawat berdasarkan undang undang dan berdasarkan studi Putusan No.1165/Pid.B/2010/PN.SDA., Putusan No.1166/Pid.B/2010/PN.SDA dan Putusan No.1167/Pid.B/2010/PN.SDA.

\section{PEMBAHASAN}

1. Prosedur Pelimpahan Wewenang Tindakan Medis Berdasarkan Undang Undang.

Dokter berwewenang melakukan tindakan kedokteran seperti yang tercantum dalam Pasal 35 huruf $f$ UU Praktik Kedokteran, setelah memenuhi prosedur perizinan praktik 
kedokteran yang diatur dalam Pasal 36 sampai dengan Pasal 38 UU Praktik Kedokteran. Wewenang tersebut didapat setelah dokter melaui pendidikan akademik dan pendidikan profesi dan mendapatkan ijazah dan melakukan sumpah/ janji profesi serta sertifikat kompetensi, setelah itu melakukan registrasi untuk mendapatkan Surat Tanda Registrasi (STR) yang dikeluarkan oleh Konsil Kedokteran Indonesia (KKI) dan memenuhi persyaratan dalam pengurusan Surat Izin Praktek (SIP).

Pasal 73 ayat (3) UU Praktik Kedokteran memberi kewenangan kepada Tenaga Kesehatan dalam hal ini perawat dalam melakukan tindakan medis yang berdasarkan pelimpahan wewenang dari dokter apabila perawat memenuhi persyaratan tata cara pelimpahan wewenang yang tercantum dalam Pasal 23 ayat (1) Permenkes No. 2052/Menkes/Per/X/ 2011 Tentang Izin Praktik dan Penatalaksanaan Praktik Kedokteran yang mengatakan bahwa: "Dokter atau dokter gigi dapat memberikan pelimpahan suatu tindakan kedokteran atau kedokteran gigi kepada perawat, bidan atau tenaga kesehatan tertentu lainnya secara tertulis dalam melaksanakan tindakan kedokteran atau kedokteran gigi".Hal ini memberikan legitimasi baik dokter sebagai pemberi wewenang maupun perawat sebagai penerima wewenang, namun Standar Prosedur Operasional (SPO) mengenai tata cara pelimpahan tersebut tidak diperjelas dalam Permenkes tersebut.

UU Keperawatan juga mengatur mengenai pelimpahan wewenang tersebut, dikatakan dalam Pasal 32 ayat (1) bahwa pelimpahan wewenang hanya dapat dilakukan secara tertulis oleh tenaga medis kepada Perawat untuk melakukan sesuatu tindakan medis dan melakukan evaluasi pelaksanaannya.Pasal 32 ayat (2) menjelaskan bahwa pelimpahan wewenang dapat dilakukan secara delegatif atau mandat, dimana pada ayat (3) menekankan tanggung jawab yang beralih kepada penerima delegasi yaitu perawat, dan delegasi hanya dapat diberikan kepada perawat profesi atau perawat vokasi terlatih yang memiliki kompetensi yang sesuai dengan pelimpahan wewenang tindakan medis tersebut disebut dalam pasal 32 ayat (4). Penjelasan ayat (4) menyatakan bahwa: "Tindakan medis yang dapat dilimpahkan secara delegatif, antara lain adalah menyuntik, memasang infus, dan memberikan imunisasi dasar sesuai dengan program pemerintah".

Pasal 32 ayat (5) menjelaskan bahwa: "Pelimpahan wewenang secara mandat diberikan oleh tenaga medis kepada Perawat untuk melakukansesuatu tindakan medis di bawah pengawasan", ayat (6) menjelaskan bahwa: "Tanggung jawab atas tindakan medis pada pelimpahan wewenang mandat sebagaimana berada pada pemberi pelimpahan wewenang". Tindakan medis yang dapat dilimpahkan secara mandat menurut penjelasan Pasal 32 ayat (5) antara lain adalah pemberian terapi parenteral dan penjahitan luka.

Pada kenyataannya berdasarkan pengamatan penulis selaku tenaga medis yang bekerja di rumah sakit, sering perawat tidak melaksanakan prosedur yang diinstruksikan oleh dokter dengan benar dalam pelaksanaan tindakan medis.Lazimnya kebiasaan tersebut turun temurun dan dilakukan dari perawat senior sampai ke perawat yunior bahkan dilakukan juga oleh siswa yang sedang praktek lapangandi rumah Sakit. Minimnya pengetahuan baik dokter yang memberikan instruksi maupun perawat yang melaksanakan instruksi dari dokter dalam melaksanakan tindakan medis tersebut. Dokter maupun perawat tidak melakukan prosedur pelimpahan wewenang tindakan medis yang sesuai dengan persyaratan yang diatur oleh undang undang. Dokter hanya memberikan instruksi singkat bahkan sering secara lisan seperti tindakan memasang 
infus, menyuntik obat dalam cairan infus atau langsung melalui intravena secara bolus, tindakan tindakan invasif minimal tersebut sering dilakukan oleh perawat dan menganggap bahwa hal itu telah menjadi tugasnya sebagai perawat.

Pasal 29 ayat (1) UU keperawatan menegaskan bahwa tugas perawat adalah yang terutama adalah sebagai pemberi Asuhan Keperawatan yang merupakan wewenang perawat yang berperan sebagai tenaga independen dan mempunyai tanggung jawab yang dipikul sendiri (personal liability) dan dapat juga bertugas sebagai pelaksana tugas berdasarkan pelimpahan wewenang. Perawat bertugas melakukan asuhan keperawatan yang bersifat caring bukan pengobatan (curing) yang merupakan otoritas seorang dokter. Perawat dapat melakukan tindakan medis hanya bila ada pelimpahan wewenang dari dokter yang pengaturannya diatur dalam Pasal 23 ayat (1) Permenkes 2052/Menkes/Per/X/2011 tentang Izin Praktik dan Pelaksanaan Praktik Kedokteran jo. Pasal 32 Undang Undang Keperawatan, dengan syarat sebagai berikut:

1. Pelimpahan wewenang dilakukan tertulis.

2. Bila kebutuhan pelayanan yang melebihi ketersediaan dokter di Fasyankes tersebut.

3. Perawat harus mempunyai kemampuan dan ketrampilan yang sesuai dengan tindakan yang akan dilimpahkan tersebut.

4. Pelaksanaan tindakan tetap di bawah pengawasan pemberi pelimpahan.

5. Pemberi pelimpahan tetap bertanggung jawab sepanjang pelaksanaan sesuai dengan pelimpahan yang diberikan.

6. Tindakan yang dilimpahkan tidak termasuk mengambil keputusan klinis sebagai dasar pelaksanaan tindakan.

7. Tindakan yang dilimpahkan tidak bersifat terus menerus.

8. Tindakan yang dapat dilimpahkan adalah menyuntik, memasang infus, memberikan imunisasi dasar sesuai dengan program pemerintah, menjahit luka dan memberikan terapi parenteral.

Pengaturan secara teknikal prosedural sangat dibutuhkan dalam melengkapi persyaratan pelimpahan wewenang tindakan medik dari dokter kepada perawat yang telah dituangkan dalam perundang-undangan. Peran Rumah Sakit sebagai Fasyankes sangat penting dalam mengatur lebih rinci tentang SPO Pelimpahn Wewenang Tindakan Medis tersebut. Peraturan tersebut dapat dibuat dalam peraturan internal staf medis (medical staff bylaws) yang merupakan pembenaran formil dari pelimpahan wewenang tersebut sehingga menjadi sebuah perlindungan bagi dokter sebagai pemebri pelimpahan, perawat sebagai penerima pelimpahan dan terutama tujuannya adalah memberikan pelayanan yang aman dan bermutu kepada pasien sebagai penerima pelayanan kesehatan.

Hubungan dokter dan perawat merupakan hubungan interkolaborasi sebagai satu tim yang seharusnya masing masing pihak dapat mengukur kompetensi dan keahliannya sendiri dan perannya dalam tim tersebut, sehingga batasan batasan tindakan jelas dalam pembagian tindakan yang mana boleh dan tidak boleh dilakukan dalam tindakan medis tersebut. Delegasi yang baik dan terencana dapat mengurangi resiko terjadinya kelalaian dalam tindakan medis yang mengakibatkan kerugian pada pasien. 


\section{Prosedur Pelimpahan Wewenang Tindakan Medis Berdasarkan Studi Kasus}

Studi Kasus tersebut berkaitan dengan kasus pelimpahan kewenangan tindakan medis, dimana ada tiga terdakwa yaitu dokter yang bernama Wida Parama Astiti yang selanjutnya disebut Terdakwa I (putusan 1165), perawat vokasi yang bernama Setyo Mujiono yang selanjutnya disebut Terdakwa II (putusan 1167) dan siswa magang yang bernam Dewi Ayu Yulmasari , yang selanjutnya disebut Terdakwa III (putusan 1166), dimana peristiwa terjadi di Rumah Sakit Umum Kryan Husada (selanjutnya disebut locus delicti) pada tanggal 29 April 2010 (selanjutnya disebut tempus delicti). Rangkaian peristiwa tersebut dimulai ketika Terdakwa I mengintruksikan penyuntikan $\mathrm{KCl}$ melalui bolus Intravena pada seorang anak yang berumur tiga tahun yang bernama Dava Chayanata Oktavianto yang selanjutnya disebut Korban, dimana perjalanan peristiwa sebagai berikut:

\section{Kasus Posisi:}

a. Terdakwa I menerima korban yang datang bersama orangtuanya di Unit Gawat Darurat (UGD) Rumah Sakit Kryan Husada pada tanggal 28 April 2010 sekitar pukul $19.00 \mathrm{WIB}$, dengan keluhan muntah mencret dan perut kembung, setelah Terdakwa I melakukan pemeriksaan dan menegakkan diagnosis penyakitnya adalah diare dan diberikan terapi obat untuk menghilangkan kembung dan mencret dan Terdakwa I menganjurkan untuk dilakukan rawat inap.

b. Terdakwa I mencatat terapi yang diberikan baik secara oral (diminum) maupun secaa parenteral (obat dimasukkan lewat infus) ke dalam Rekam Medik Korban, kemudian Terdakwa I memberikan instruksi kepada Terdakwa II untuk melakukan tindakan medis yang sesuai dengan instruksi Terdakwa I dalam Rekam Medik.

c. Terdakwa II melakukan instruksi Terdakwa I dan mengantarkan Korban untuk dirawat di Ruang Mawar Kelas III di lantai II.

d. Pada tanggal 29 April 2010 pagi hari sekitar puku 09.00 WIB, terdakwa I melakukan visite (kunjungan) kepada Korban yang didampingi oleh Terdakwa II untuk melihat perkembangan penyakit dan melakukan pemeriksaan fisik.

e. Pada saat kunjungan tersebut, ibu korban mengeluhkan bahwa Korban masih kembung dan meminta tambahan obat yang bukan obat minum, tetapi Terdakwa I tetap menyarankan untuk meminumkan obat yang telah diberikan tersebut.

f. Pada saat Terdakwa II sedang berdinas di Ruang Perawatan Anak Mawar, nenek korban mendatang Terdakwa II untuk meminta tambahan obat injeksi karena perut korban masih kembung.

g. Atas desakan nenek korban, Terdakwa II menghubungi Terdakwa I yang sedang berada di poliklinik di lantai I untuk melaporkan bahwa keluarga Korban meminta tambahan obat injeksi.

h. Terdakwa I akhirnya mengabulkan permintaan keluarga Korban dan memberikan instruksi secara lisan tanpa penjelasan secara detail dan jelas untuk menyuntikkan $\mathrm{KCl}$ setengah ampul dengan bolus Intravena pelan pelan. 
i. Terdakwa II tanpa mengerti instruksi tersebut dan tanpa meminta penjelasan lebih lanjut bagaimana prosedur penyuntikan $\mathrm{KCl}$ tersebut dan tanpa mengetahui dosis dari $\mathrm{KCl}$ yang disesuaikan dengan seorang anak berumur tiga tahun, mempersiapkan obat dalam spuit $10 \mathrm{cc}$.

j. Setelah obat $\mathrm{KCl}$ telah dimasukkan dalam spuit $10 \mathrm{cc}$, Terdakwa II menginstruksikan kepada Terdakwa III yang merupakan siswi magang yang belum mempunyai kompetensi dan wewenang untuk melakukan tindakan medis serta tidak dilakukan pengawasan dalam pelaksanaan tindakan tersebut agar menyuntikkan obat tersebut pada korban dengan cara bolus intravena pelan pelan.

k. Terdakwa III menerima instruksi dari Terdakwa II tanpa menanyakan bagaimana prosedur penyuntikan tersebut dan obat apa yang disuntikkan dan Terdakwa III tidak menolak melakukan tindakan tersebut karena takut tidak diluluskan dalam praktek lapangan tersebut.

I. Terdakwa III melakukan penyuntikan tersebut tanpa pengawasan dari Terdakwa II, pada saat dilakukan suntikan Korban menangis tetapi nenek korban memaksa untuk menyuntikkan obat tersebut sampai habis.

m. Selang 10 menit, Korban mengalami kejang kejang, dan terdakwa II melakukan pertolongan pertama dengan memasukkan obat melalui dubur dan memberikan oksigen.

n. Kemudian Terdakwa I datang untuk melakukan kejut jantung tapi nyawa Korban tidak tertolong

o. Direktur Rumah Sakit datang untuk memastikan kematian korban.

\section{Analisis Kasus}

\section{a. Terdakwa I (Putusan nomor 1165/Pid.B/2010/PN.SDA)}

1) Dasar Hukum:

(a) UU Praktik Kedokteran

Terdakwa I telah melanggar Pasal 44 ayat (1) tidak mengikuti standar pelayanan kedokteran dan melanggarPasal 46 ayat (1) karena tidak melakukan pencatatan terapi yang diinstruksikan dalam Rekam Medik.

(b) UU Keperawatan

Terdakwa I melanggar Pasal 32 (1) pelimpahan wewenang harus dilakukan secara tertulis dan melanggar Pasal 32 ayat (4) pelimpahan wewenang tindakan medis diberikan kepada perawat vokasi yang terlatih dan memiliki kompetensi yang sesuai dengan tindakan tersebut.

(c) Permenkes No.2052/Menkes/Per/X/2011 Tentang Izin Praktik Dan Pelaksanaan Praktik KedokteranTerdakwa I telah melanggar pasal 21 tindakan medis yang diinstruksikan tidak berdasarkan :Standar Pelayanan Minimal: tidak memiliki pengetahuan tentang dosis obat dan cara penyuntikan sera efek samping dari obat, Standar Profesi: tidak mempunyaikemampuan rata rata seorangdokter umum pada situasi dan tempat yang sama, tidak memiliki kecermatan dan ketelitian, serta tidak 
mempunyai kompetensi berdasarkan pendidikan dan keahlian seorang dokter, SPO: tidak menguasai SPO tentang tata cara penyuntikan obat $\mathrm{KCl}$ melalui pengenceran secara drip bukan bolus intravena, Kebutuhan medis pasien: karena desakan orang tua yang sebenarnya tidak ada indikasi medis terapi parenteral (obat yang dimasukkan melalui injeksi).

(d) Terdakwa I melanggar Pasal 23 tentang Persyaratan Pelimpahan Tindakan Medis yaitu:tidak melakukan pengawasan terhadap Perawat Pelaksana Pelimpahan (Terdakwa II) dan tidak melihat kemampuan dan ketrampilan yang dipunyai oleh Penerima Pelimpahan (Terdakwa II).

2) Dakwaan

Primair: Perbuatan terdakwa diancam pidana dalam Pasal 359 KUHP jo Pasal 361 KUHP. Subsidair: Perbuatan terdakwa diancam pidana dalam Pasal 359 KUHP

3) Barang Bukti

(a) satu botol kecil sisa obat Neo Kaolana Kaolin, Pectin Suspension

(b) satu buah alat suntik/ spuite ukuran $10 \mathrm{ml}$

(c) satu botol kecil sisa obat Antasida Doen

(d) satu botol kecil sisa obat Otsu $\mathrm{KCl} 7,46 \%$

(e) Kotoran korban yang terdapat dalam kapas

(f) satu berkas rahasia medis RSU Krian Husada.Pasien Dava Chayanata Oktavianto

4) Unsur Unsur Pidana

(a) Unsur Barang Siapa

Orang yang telah melaksanakan penyuntikan, yang menyuruh melakukan penyuntikan dan melakukan penyimpangan di dalam melaksanakan tindakan medis atau tindakan kedokteran terhadap pasien atas nama Dava Chayanata Octavianto sehingga mengakibatkan matinya pasien tersebut jelas adalah orang yang harus bertanggung jawab secara hukum.

(b) Unsur Melawan Hukum

Tindakan medis atau tindakan kedokteran yang telah dilakukan pada pasien yang bernama Dava Chayanata Octavianto, umur 3 tahun, yang berdasarkan atas diagnosa dokter jaga yang ada di UGD RSU Krian Husada yaitu Dr.Wida Parama Astiti, pasien tersebut dinyatakan rawat inap dan selanjutnya dilakukan rawat inap di ruang anak kelas III Mawar Putih 1, tercatat dengan nomor register pasien nomor 008065 penyakit yang diderita berdasarkan diagnosa dokter adalah Diare dengan keluhan berak berak, kembung dan muntah, tindakan medis tersebut berupa : Penggunaan injeksi KCL pada anak yang berusia 3 tahun dibenarkan untuk kepentingan menghilangkan kembung, yang terpenting adalah cara penggunaan atau penyuntikan dilakukan secara benar. Prosedur yang benar dalam pemberian $\mathrm{KCL}$ adalah sebelum dimasukkan harus 
dilakukan pengenceran atau dicampurkan ke dalam cairan infus sehingga masuk kedalam tubuh pasien secara perlahan lahan melalui tetesan infus. Penyuntikan $\mathrm{KCL}$ pada selang infus tempat injeksi yang disebut dengan injeksi bolus hal ini jelas salah atau menyalahi prosedur.

(c) Unsur Akibat

Penyebab kematian korban atas nama Dava Chayanata Oktavianto adalah disebabkan oleh adanya kadar kalium yang tinggi dalam darah korban sehingga berakibat kematian

5) Putusan

Unsur Unsur Pidana dalam tindakan terdakwa I memenuhi persyaratan yakni Terdakwa I sebagai subyek hukum mampu bertanggung jawab dan cakap dalam arti sehat jasmani dan rohani, terdapat unsur kealpaan (culpa) yaitu kareana kealpaannya menyebabkan matinya orang serta tidak ada alasan pemaaf dan alasan pembenar, sehingga terdakwa dikenai dakwaan Pasal 359 KUHP jo Pasal 361 KUHP dengan putusan:

Terdakwa I telah terbukti secara sah dan meyakinkan bersalah melakukan tindak pidana karena salahnya menyebabkan matinya orang yang dilakukan dalam melakukan suatu jabatan atau pekerjaannya, sebagaimana dakwaan primair menjatukan pidana penjara selama sepuluh bulan.

\section{b. Terdakwa II (Putusan nomor 1167/Pid.B/2010/PN.SDA)}

\begin{tabular}{|c|c|}
\hline Nomor & 1167/Pid.B/2010/PN.Sda. \\
\hline Tingkat Proses & Pertama \\
\hline Klasifikasi & Pidana \\
\hline Sub Klasifikasi & $=$ \\
\hline $\begin{array}{ll}\text { Jenis } & \text { Lembaga } \\
\text { Peradilan } & \end{array}$ & PN \\
\hline Lembaga Peradilan & PN SIDOARJO \\
\hline Para Pihak & SETYO MUJIONO \\
\hline Tahun & $\underline{2011}$ \\
\hline Tanggal Musyawarah & 11-07-2011 \\
\hline Tanggal Dibacakan & $19-07-2011$ \\
\hline Amar & LEPAS \\
\hline Catatan Amar & 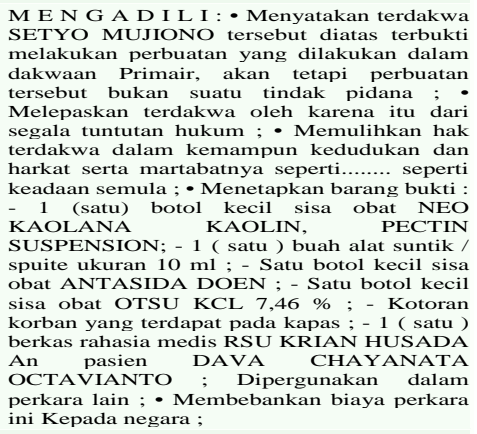 \\
\hline Hakim & Majelis \\
\hline Hakim Ketua & H. YAHYA SYAM, ,SH.MH. \\
\hline
\end{tabular}




\section{1) Analisa Kasus}

Dasar Hukum:

(a) UU Keperawatan

Pasal 28 ayat (2) huruf c Praktik Keperawatan harus didasarkan pada kode etik, standar pelayanan, standar profesi, dan standar prosedur operasional. Pasal 29 ayat (3) Pelaksanaan tugas Perawat harus dilaksanakan secara bertanggung jawab dan akuntabel.

(b) Pasal 23 ayat (1) Permenkes 2052/Menkes/ Per/X/2011 tentang Izin Praktik dan Pelaksanaan Praktik Kedokteran jo.Pasal 32 Undang Undang Keperawatan syarat pelimpahan wewenang: mengatakan bahwa: Perawat harus mempunyai kemampuan dan ketrampilan yang sesuai dengan tindakan yang akan dilimpahkan tersebut.Perawat tidak menjalankan instruksi dokter dengan benar.Tidak menanyakan bagaiman prosedur penyuntikan $\mathrm{KCl}$ tersebut.

(c) Unsur Unsur Pidana dalam tindakan terdakwa II memenuhi persyaratan yakni Terdakwa II sebagai subyek hukum mampu bertanggung jawab dan cakap dalam arti sehat jasmani dan rohani, terdapat unsur kealpaan (culpa) yaitu karena kealpaannya menyebabkan matinya orang serta tidak ada alasan pemaaf tetapi ada alasan pembenar yaitu karena perintah atasan, sehingga terdakwa II telah terbukti secara sah dan meyakinkan bersalah melakukan tindak pidana karena salahnya menyebabkan matinya orang karena perintah atasan dilepaskan dari tuntutan pidana.

\section{c. Terdakwa III (Putusan Nomor 1166/Pid.B/2010/PN.SDA}

Subyek Hukum: tidak cakap dan tidak mampu bertanggung jawab ada alasan pemaaf dan pembenar sehingga perbuatan dianggap tidak ada dan batal demi hukum, dakwaan: telah terbukti secara sah dan meyakinkan bersalah melakukan tindak pidana karena salahnya menyebabkan matinya orang karena perintah atasan dilepaskan dari tuntutan pidana dan terdakwa tidak memenuhi syarat dapat dipidana.

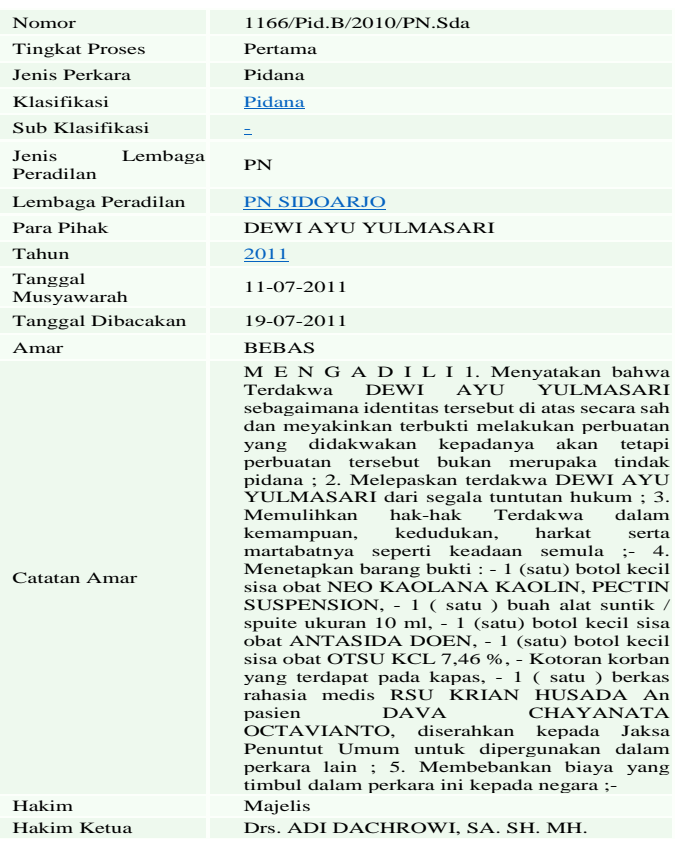




\section{Resume Kasus}

a. Tindakan seorang dokter dalam memerintahkan dan menginstruksikan kepada perawat untuk melakukan tindakan medis adalah sah dan benar yang terpenting tindakan tersebut secara tertulis, tercatat dengan benar dalam rekam medik pasien dan dalam pelaksanaanya tidak ada penyimpangan serta sesuai dengan perintah yang diberikan.

b. Siswa magang belum dapat dikatakan sebagai perawat mempunyai wewenang melakukan tindakan upaya kesehatan.

c. Bila terjadi penyimpangan yang dilakukan di luar perintah dokter jelas perawat tersebut yang bertanggung jawab tetapi bila jika semua dilakukan dengan benar oleh perawat sesuai dengan perintah dokter dan sesuai dengan yang tercatat dalam rekam medik pasien namun terdapat adanya kekeliruan maka tanggung jawab berada pada dokter yang memerintahkan.

d. Bahwa ada kewajiban dan keharusan bagi perawat untuk mempertanyakan kepada dokter yang memerintahkan atau mengindtruksikan sebuah tindakan

medis jika memang benar benar belum memahami perintah dan cara tindakan yang harus dilakukan hal tersebut dimaksudkan untuk menghindari adanya kekeliruan dalam mengambil tindakan medis sesuai perintah dokter, sedangkan untuk penjabaran perintah dari seorang dokter jelas tidak dibenarkan dan menyalahi prosedur.

e. Injeksi $\mathrm{KCl}$ terhadap pasien pada selang infus yang disebut bolus jelas salah dan tidak sesuai dengan prosedur, karena penyuntikan $\mathrm{KCl}$ sedianya harus dimasukkan dalam botol cairan infus dilakukan melalui drip sehingga masuk ke dalam tubuh melalui infus secara pelan pelan.

f. Hasil pemeriksaan visum et repertum jenazah Nomor: KF:10.341 yang ditandatangani oleh Dr. Evi Diana Fitri yang dikeluarkan RSU Dr. Sutomo Instalasi Kedokteran Forensik dan Medikolegal sesuai dengan permintaan Kepolisian Sektor Belong Bendo Polres Sidoarjo sesuai dengan surat nomor B/07/IV/2010/Polres tanggal 29 April 2010 kepada Kepala Rumah Sakit Dr. Sutomo Surabaya, menyimpulkan bahwa:

1) Jenasah anak laki-laki berumur lebih kurang tiga tahun, panjang badan seratus enam centimeter, berat delapan belas kilogram, wama kulit kuning langsat, keadaan gizi cukup;

2) Pada pemeriksaan luar: ditemukan bintik-bintik pendarahan (ptechie) pada selaput lendIr mata. Hal ini lazim ditemukan pada keadaan mati lemas (asfiksia);

3) Pada pemeriksaan dalam tidak ditemukan kelainan fisik yang nyata;

4) Pada pemeriksaan tambahan:

(a) Pemeriksaan histopalogi: ditemukan kelainan organ yang lazim didapatkan pada jenazah mati lemas.

(b) Pemeriksaan toksologi: tidak ditemukan racun

(c) Pemeriksaan elektrolit ketidakseimbangan kadar elektrolit dalam darah yang berarti telah terjadi kerusakan jaringan yang mendadak (akut) dan 
ditemukan peningkatan kadar kalium yang sangat tinggi hingga tujuh sampai delapan kali lipat dari nilai normal

(d) Peningkatan kadar kalium yang sangat tinggi hingga tujuh sampai delapan kali lipat dari nilai normal menyebabkan gangguan irama jantung hingga berhentinya kerja jantung yang menyebabkan kematian.

Hal hal diatas dapat disimpulkan bahwa telah terjadi kelalaian yang dilakukan tenaga medis dan tenaga perawat dalam pelimpahan wewenang tindakan medis sehingga menimbulkan kematian pada anak Dava Chayanata Oktavianto yaitu:

1. Pelaksanaan penyuntikan tidak sesuai dengan instruksi atau petunjuk dokter, tidak dipertanyakan dengan jelas prosedur dan tata cara penyuntikan $\mathrm{KCL}$ terhadap pasien oleh perawat kepada dokter yang memberikan instruksi atau sebaliknya dokter tidak memberikan instruksi secara benar kepada perawat yang melaksanakan.

2. Adanya penjabaran perintah dari dokter yang diberikan perawat oleh perawat itu sendiri berkaitan dengan pelaksanaan penyuntikan atau injeksi KCL kepada pasien atau korban atas nama Dava Chayanata Oktavianto yang sedianya harusdilakukan perawat itu sendiri namun perawat tersebut memerintah kepada orang lain yang hal imi kepada siswa magang yang tidak atau belum memiliki kredibilitas sesuai dengan aturan dan perundang undangan yang berlaku sehingga dalam pelaksanaannya tidak dapat berjalan maksimal.

3. Jika perawat tersebut tidak melaksanakan instruksi sesuai dengan yang telah diberikan oleh dokter maka jelas yang melakukan kelalaian adalah perawat itu sendiri demikian sebaliknya.

\section{Studi Kasus Putusan}

\begin{tabular}{|c|c|c|c|}
\hline $\begin{array}{c}\text { Dr.Wida Parama Astiti } \\
\text { Dr.Umum }\end{array}$ & $\begin{array}{l}\text { Setyo Mujiono } \\
\text { Perawat Vokasi }\end{array}$ & $\begin{array}{l}\text { Dewi Ayu Yulmasari } \\
\text { Siswa Magang Poltekes }\end{array}$ & $\begin{array}{l}\text { va Chayanata Oktavianto } \\
\text { Pasien }\end{array}$ \\
\hline $\begin{array}{l}\text { Subyek hukum : cakap dan dapat } \\
\text { bertanggung jawab } \\
\text { Tidak ada alasan pemaaf dan } \\
\text { pembenar } \\
\text { Kesalahan Prosedur } \\
\text { a. Instruksi tidak jelas, tidak benar } \\
\text { dan tidak tertulis } \\
\text { b. tidak dicatat dalam RM Pasien } \\
\text { c. Terdapat kesalahan dalam } \\
\text { instruksi : suntik IV bolus pelan } \\
\text { delan 1/2 ampul } \\
\text { d. Tidak mengetahui SPO } \\
\text { e. Tidak mengikuti SPM } \\
\text { f. Tidak bekarena salahnya } \\
\text { menyebabkan matinya orang } \\
\text { yang dilakukan dalam } \\
\text { melakukan suatu jabatan atau } \\
\text { pekerjaannya, rdasarkan SP }\end{array}$ & $\begin{array}{l}\text { Kesalahan Prosedur } \\
\text { a. Instruksi dokter tidak } \\
\text { dilaksanakan dengan benar } \\
\text { b. Pelimpahan wewenang kepada } \\
\text { siswa yang belum mempunyai } \\
\text { kompetensi } \\
\text { c. Tidak mengikuti SPO } \\
\text { d. Tidak mengetahui dosis obat } \\
\text { dan efek samping }\end{array}$ & $\begin{array}{l}\text { Kesalahan Prosedur } \\
\text { a. Penyuntikan } \mathrm{KCl} \text { tanpa } \\
\text { mengetahui isi obat yang } \\
\text { disuntik } \\
\text { b. Tidak bertanya bagaimana } \\
\text { prosedur penyuntikannya } \\
\text { c. Tidak mempunyai kompetensi } \\
\text { dan wewenang } \\
\text { d. Tidak menolak bila tidak mampu } \\
\begin{array}{c}\text { Lepas karena perintah } \\
\text { atasan }\end{array}\end{array}$ & $\begin{array}{c}\text { Kematian yang } \\
\text { disebabkan oleh kelalaian } \\
\text { dalam prosedur tindakan } \\
\text { medik }\end{array}$ \\
\hline
\end{tabular}

Telah Terbukti Secara Sah Dan Meyakinkan Bersalah Melakukan Tindak Pidana Pasal 359 KUHP Jo Pasal 361 KUHP 


\section{PENUTUP}

\section{KESIMPULAN}

Berdasarkan permasalahan permasalahan beserta pembahasannya dapat disimpulkan bahwa:

1. Prosedur pelimpahan wewenang tindakan medis dari dokter kepada perawat berdasarkan perundang undangan yaitu UU Praktik Kedokteran, UU Keperawatan, Permenkes No.2052/Menkes/Per/ X/2011 Tentang Izin dan Pelaksanaan Praktik Kedokteran telah mengatur persyaratan dan prosedur pelimpahan wewenang tindakan medis, namun Standar Prosedur Operasional (SPO) dan batasan batasan pelimpahan wewenang dalam melakukan tindakan medis belum diatur sehingga menimbulkan ketidakpastian dan kekosongan hukum yang menimbulkan ketidakadilan dalam perlakuan perlindungan hukum bagi profesi medis maupun profesi tenaga kesehatan serta merugikan hak pengguna kesehatan dalam mendapatkan pelayanan yang aman dan bermutu.

2. Perluasan wewenang yang dijabarkan baik oleh dokter maupun oleh perawat tidak sesuai dengan kriteria tindakan yang diatur dalam perundang-undangan, tindakan apa saja yang dapat dilimpahkan secara delegatif dan tindakan apa saja yang dapat dilimpahkan secara mandat. Hal ini juga melanggar hak otonomi pasien dalam mendapatkan pelayanan yang aman dan bermutu dengan prinsip kehati-hatian dan kecermatan yang sesuai dengan kompetensi profesi tersebut.

3. Prosedur pelimpahan wewenang tindakan medis dari dokter kepada perawat berdasarkan studi kasus putusan, terdapat ketidakjelasan dalam konsep dalam tindakan medis dimana seyogyanya sebuah putusan dalam melakukan tindakan medis yang merupakan domain dari dokter dan hanya pelaksanaan tindakan medis sementara yang bersifat perbantuan maka diberikan pelimpahan wewenangnya kepada perawat, sehingga dokter tidak dapat memberikan wewenang penuh secara delegatif dan tanggung jawab serta tanggunggugat bila terdapat kelalaian yang diperbuat oleh perawat juga merupakan tanggung jawab dan tanggunggugat dokter.

4. Delegatif dalam keputusan melakukan tindakan medis tidak diperbolehkan karena menyangkut tindakan terhadap tubuh manusia dimana dokter yang mempunyai kompetensi dan keahlian saja yang dapat memprediksi proses dan hasil dari tindakan tersebut, sedangkan perawat tidak mempunyai kompetensi di bidang tersebut.Sinkronisasi antara prosedur pelimpahan wewenang tindakan medis dari dokter kepada perawat yang diatur dalam undang undang tidak diterapkan dalam kenyataannya di lapangan karena anggapan bahwa sudah merupakan suatu kelaziman untuk melakukan tindakan medis tersebut dan perawat seolah olah menganggap tindakan tersebut merupakan tugas dan wewenangnya.

\section{SARAN}

1. Bagi organisasi profesi IDI dan PPNI harus memperhatikan anggota anggotanya agar lebih mengindahkan Standar Profesi dan prinsip kehati hatian, kecermatan dan keseksamaan harus selalu dijaga dan ditingkatkan.

2. Peraturan teknis operasional tentang tata cara pelimpahan wewenang dalam tindakan medis beserta jenis jenis tindakan apa saja yang boleh dilimpahkan yang merupakan turunan dari UU Praktek Kedokteran, UU Keperawatan dan UU Rumah Sakit harus 
segera dibuat agar adanya kepastian hukum dan keadilan baik bagi pemberi jasa pelayanan maupun penerima jasa pelayanan kesehatan.

3. Konsepsi tentang tanggungjawab dan tanggunggugat secara hukum baik kepada dokter sebagai pemberi wewenang maupun kepada perawat sebagai penerima wewenang harus jelas batasan batasannya pihak mana yang harus bertanggung jawab dan bertanggunggugat bila terdapat suatu kesalahan atau kelalaian dalam pelaksanaan tindakan medis.

4. Bagi dokter harus selalu memberikan instruksi secara jelas dan detail serta memberikan penjelasan bagaimana pelaksanaan tindakan medis tersebut dan resiko serta akibat dari tindakan yang tidak benar dan menjelaskan juga bagaimana mengatasi bila timbul resiko.

5. Bagi perawat harus selalu berpegang pada prinsip kehati hatian serta meningkatkan kompetensi sesuai dengan keahliannya dan berani bertanya serta berani menolak jika sesuatu belum jelas atau belum mampu melakukan tindakan medis tersebut.

6. Bagi praktisi profesi hukum hakim, jaksa, advokat serta penyidik lebih memahami hukum kesehatan dan hukum kedokteran pada khususnya agar tidak terjadi ketidakadilan dalam memutus perkara yang melibatkan profesi kesehatan dengan permasalahan dalam dunia kedokteran yang selalu tidak pasti dan penuh resiko

\section{DAFTAR PUSTAKA}

Adji, Oemar Seno, 1991, Etika Profesional Dan Hukum Profesi Advokat, Jakarta:Erlangga.

Guwandi, J, 1991, Dokter dan Rumah Sakit, Jakarta: Balai Penerbit FKUI

Guwandi, J, 2005, Hospital Law, Jakarta: FKUI.

Hanafiah, Jusuf dan Amri Amir, 2016, Etika Kedokteran dan Hukum Kesehatan, Jakarta: EGC.

Hatta, Moh., 2013, Hukum Kesehatan dan Sengketa Medik, Yogyakarta: Liberty.

Ibrahim, Johny, 2006, Teori Metodologi Penelitian Hukum Normatif, Jawa Timur: Bayu Media.

Koeswadji, Hermien Hadiati, 1998, Pihak Hukum Kedokteran (Studi Tentang HubunganHukumDalam Mana Dokter Sebagai Salah Satu), Bandung:PT.Citra Aditya Bakti.

Koeswadji, Hermien Hadiati, 2002, Hukum Untuk Perumahsakitan, Bandung: PT.Citra Aditya Bakti.

Leenen, H. J. J., 1981, Gezondheidszorg En Recht, Een Gezondheidsrechtelijke Studie, Alphen AanDenRijn/ Brussel: Samson Uitgeverij.

Nasution, Bahder Johan, 2005, Hukum Kesehatan Pertanggung Jawaban Dokter, Jakarta: PT.Rineka Cipta.

Sidharta, Bernard Arief, 2009, Refleksi tentang Struktur Ilmu Hukum, Bandung: Mandar Maju

Soekanto, Soerjono, 1982, Pengantar Penelitian Hukum, Jakarta: Universitas Indonesia Press.

Soekanto, Soerjono, dan Sri Mamudji, 2001, Penelitian Hukum Normatif:SuatuTinjauan Singkat, Jakarta:Raja Grafindo Persada. 
Soerjowinoto, Petrus, 2015, Ilmu Hukum Suatu Pengantar Buku Panduan Mahasiswa,Semarang:Unika Soegijapranata.

Supriadi, Wila Chandrawila, 2001, Hukum Kedokteran, Bandung: Mandar Maju.

Van der Mijn, 1984,"The Development of Health Law in the Nederlands", Makalah $\quad$ yang disampaikan dalam SeminarSehari"Issues of Health Law", TimPengkajian Hukum Kedokteran,Badan Pembinaan Hukum Nasional Departemen Kehakiman RI bekerja sama dengan PERHUKI dan PB IDI, Jakarta

Yustina, Endang Wahyati, 2012, Mengenal Hukum Rumah Sakit, Keni Media.

\section{Kamus}

Alwi,Hasan, Pemred, 2005, Kamus Besar Bahasa Indonesia, Ed.Ketiga,Jakarta:Departemen Pendidikan Nasional dan Balai Pustaka.

Kamus Besar Bahasa Indonesia, 2008, Pusat Bahasa Departemen Pendidikan Nasional.

\section{Perundang-Undangan}

RI, Undang-Undang Dasar 1945.

RI, Undang-Undang Nomor 29 Tahun 2004 tentang Praktik Kedokteran.

RI, Undang-Undang Nomor 36 Tahun 2009 tentang Kesehatan.

RI, Undang- Undang Nomor 36 Tahun 2014 tentang Tenaga Kesehatan.

RI, Undang-Undang Nomor 38 Tahun 2014 tentang Keperawatan

RI, Peraturan Menteri Kesehatan Republik Indonesia Nomor 2052 Tahun 2011Tentang Izin Praktikdan Pelaksanaan Praktik Kedokteran.

RI, Peraturan Menteri Kesehatan Republik Indonesia Nomor 17 Tahun 2013 Tentang Perubahan Atas Peraturan Menteri Kesehatan Nomor Hk.02.02/Menkes/148/I/2010Tentang IzindanPenyelenggaraan Praktik Perawat.

RI, Peraturan Menteri Kesehatan Republik Indonesia Nomor 290 Tahun 2008 Tentang Persetujuan Tindakan Kedokteran.

\section{Putusan Pengadilan}

Pengadilan Negeri Sidoarjo. Putusan No. 1165/Pid.B/2010/PN.SDA

Pengadilan Negeri Sidoarjo. Putusan No. 1166/Pid.B/2010/PN.SDA

Pengadilan Negeri Sidoarjo. Putusan No. 1167/Pid.B/2010/PN.SDA 